\title{
Fifteen Years of Airborne Particulates in Vitro Toxicology in Milano: Lessons and Perspectives Learned
}

\author{
Eleonora Marta Longhin ${ }^{1}$, Paride Mantecca ${ }^{2}$ (1) and Maurizio Gualtieri ${ }^{3, *}$ (C) \\ 1 Health Effects Laboratory, Department for Environmental Chemistry, NILU-Norwegian Institute for Air \\ Research, Instituttveien 18, 2007 Kjeller, Norway; eml@nilu.no \\ 2 Department of Earth and Environmental Sciences, Research Center POLARIS, University of Milano-Bicocca, \\ 20126 Milan, Italy; paride.mantecca@unimib.it \\ 3 ENEA SSPT-MET-INAT Bologna Research Centre, Via Martiri di Monte Sole, 4, 40129 Bologna, Italy \\ * Correspondence: maurizio.gualtieri@enea.it
}

Received: 23 January 2020; Accepted: 1 April 2020; Published: 3 April 2020

\begin{abstract}
Air pollution is one of the world's leading environmental causes of death. The epidemiological relationship between outdoor air pollution and the onset of health diseases associated with death is now well established. Relevant toxicological proofs are now dissecting the molecular processes that cause inflammation, reactive species generation, and DNA damage. In addition, new data are pointing out the role of airborne particulates in the modulation of genes and microRNAs potentially involved in the onset of human diseases. In the present review we collect the relevant findings on airborne particulates of one of the biggest hot spots of air pollution in Europe (i.e., the Po Valley), in the largest urban area of this region, Milan. The different aerodynamic fractions are discussed separately with a specific focus on fine and ultrafine particles that are now the main focus of several studies. Results are compared with more recent international findings. Possible future perspectives of research are proposed to create a new discussion among scientists working on the toxicological effects of airborne particles.
\end{abstract}

Keywords: $\mathrm{PM}_{10} ; \mathrm{PM}_{2.5}$; ultrafine particulate matter (UFP); inflammation; oxidative species; DNA damage; epigenetic modification

\section{Air Pollution in Urban European Cities: The Case Study of Milan}

Milan is the biggest city in the Po Valley area with 1.3 million inhabitants, the second largest in Italy after Rome, and one of the most populous metropolitan cities in Europe with more than 7.5 million inhabitants (considering the Milan Metropolitan area). Air pollution in the Po Valley region is a matter of concern. The latest air quality report from the European Environment Agency (EEA) [1] shows that, in 2016, the majority of monitoring stations of the Po Valley registered a mean annual concentration of particulate matter, with mean aerodynamic diameter lower than $10 \mu \mathrm{m}\left(\mathrm{PM}_{10}\right)$, higher than the annual threshold of $40 \mu \mathrm{g} / \mathrm{m}^{3}$. Similar results were also found from the monitoring stations located in Milan Metropolitan Area, where particulate matter (PM) still represents one of the most critical environmental issues for its impact on human health [2]. Since the 1990s, local, regional, and national authorities have made efforts to reduce airborne particles concentration, and significant improvements were achieved. Nonetheless, in the last decade, the rate of reduction of air pollution over the Po Valley region slowed [3,4], mainly due to the geomorphological condition of this area. In fact, the rate of reduction remained significant at urban stations and was mainly associated with the renewal of circulating vehicle fleets [3]. The latest data available for the city of Milan (data from the EEA website, https://www.eea.europa.eu/data-and-maps/data/aqereporting-8\#tab-figures-produced and 
http://discomap.eea.europa.eu/map/fme/AirQualityExport.htm and https://www.eea.europa.eu/dataand-maps/indicators/exceedance-of-air-quality-limit-3/assessment-5) confirm that annual averages of fine particulate matter, i.e. particles with aerodynamic diameter lower than $2.5 \mu \mathrm{m}\left(\mathrm{PM}_{2.5}\right)$, measured at an urban traffic (Via Senato) and at an urban background (Via Pascal, Città Studi) station, are not significantly different. These data also show that the annual limit of $25 \mu \mathrm{g} / \mathrm{m}^{3}$ set by the European Union (EU) Directive 2008/50/EC is not always respected. Therefore, due to its peculiar geomorphological conditions, and as the biggest city in the north of Italy, the city of Milan represents a significant case study at the European level for comprehension of the potential impacts of air pollution in an exposed population [2]. In this context, in 2008, a research center on Particulate Matter and Health Risk (POLARIS) was instituted at the Department of Environmental Sciences (now Dept. of Earth and Environmental Sciences) of the University of Milano-Bicocca. POLARIS is a multidisciplinary scientific body for chemical, physical, biological, toxicological, clinical, and epidemiological research on air pollution in Milan, and more in general, in the Lombardy region and Italy. Over the last twelve years of activity, POLARIS researchers uncovered and published significant and interesting processes related to air pollution, including particulate matter (PM) chemical and microbiological characterization, in vitro and in vivo toxicological effects, as well as clinical and epidemiological studies [5-8].

Nowadays the presence of micro and nano-plastic debris in the environment is attracting increasing scientific interest. A recent study [9] reported the presence of airborne microplastics in European and Chinese cities and regions, with fragments and fibers derived from the wearing out of plastic goods (i.e., synthetic textiles, waste treatments, industrial emissions, etc.). In addition to these new emerging plastic particles, the wearing out of tires is nowadays (re)considered as a significant emission source of plastic particles $[10,11]$ with an estimated contribution of $3 \%-7 \%$ to $\mathrm{PM}_{2.5}$.

This review summarizes the most relevant results obtained through in vitro studies on the toxicological impact of airborne PM, also considering the international literature, and proposes the focal research points that, in the coming years, researchers, who deal with the mechanisms and modes of action related to airborne pollution and health risks, should take in consideration.

\section{Coarse $P M$ and $P_{10}$}

$\mathrm{PM}_{10}$ was the first fractional dimension subject to EU environmental regulation, with limits for atmospheric concentrations since 1999 (First Daughter Directive to the Air Quality Framework Directive). As a consequence, it was also the fraction that first received attention from the community of environmental toxicologists. However, in the last years, the interest on $\mathrm{PM}_{10}$ toxicological potential has received less and less attention if compared to fine PM (i.e., particulates with an aerodynamic diameter lower than $\left.2.5 \mu \mathrm{m}\left(\mathrm{PM}_{2.5}\right)\right)$, and ultrafine $\mathrm{PM}$ (i.e., particulates with an aerodynamic diameter lower than $100 \mathrm{~nm}$, known as $\mathrm{PM}_{0.1}$ or ultrafine particulate matter (UFP, i.e. particles with aerodynamic diameter lower that $100 \mathrm{~nm}$ )).

The reasons for this reduced research interest stand in the increased number of studies focusing on the effects of selected emission sources (vehicular emissions, biomass burning, ship emissions, etc.) and by the increasing evidence from epidemiological studies showing a strong correlation between fine PM exposure and adverse health effects [12,13]. Nonetheless, a clear relationship between coarse PM and biological effects, in exposed models in vitro and in vivo, has been largely reported [14,15]. Indeed, the capability of coarse PM to induce inflammation in cells has been associated to the higher content of crustal elements and fragments from bacteria and other biological components. The question, largely discussed, is at what extent are $\mathrm{PM}_{10}$ and coarse $\mathrm{PM}$ (i.e., $\mathrm{PM}$ fraction with mean aerodynamic diameter lower than $10 \mu \mathrm{m}$ and higher than $\left.2.5 \mu \mathrm{m}\left(\mathrm{PM}_{10-2.5}\right)\right)$ relevant to explain adverse human health effects. Although out of the scope of this review, it is worth mentioning that coarse airborne particles deposited in the tracheobronchial respiratory tract may end into the gastrointestinal system [16,17]. Cilia of bronchial cells are the engine of the mucociliary escalator [18] that transports the mucus, and the particles trapped in it, from the lungs up to the larynx where it is swallowed. The particles thus enter the gastrointestinal (GI) system where they may interact with GI tissues and fluids [19-21]. In 
the alveolar region particles may be actively removed by specialized cells (macrophages) and other mechanisms (reviewed in [22]). Considering the deposition curves of particulates in the lung, larger $\mathrm{PM}_{10}$ particles should mainly deposit in the upper respiratory tract affecting the bronchial and thoracic regions [23]. The effects of these particles on nasal and bronchial epithelial cells have been therefore considered relevant for the assessment of toxicological effects of airborne $\mathrm{PM}_{10}$. The reported effects, which include inflammation, oxidative stress, DNA damage, and cell death, have been related to the activation of different biological pathways [24-26]. Given the significant difference registered in Milan PM chemical composition during cold and warm seasons [8,27], an evaluation of the biological effects of $\mathrm{PM}_{10}$ was performed comparing the potency of samples obtained during winter and summer seasons. The experience collected over a decade showed two main different impacts of these particulates: summer $\mathrm{PM}_{10}$ was able to induce an increase in inflammatory mediators in the exposed in vitro systems [14], also activating the nucleotide-binding domain, leucine-rich-containing family, pyrin domain-containing-3 OR Nod-like receptor protein 3 (NLRP3) inflammasome and, consequently inducing the release of interleukin (IL)-1 $\beta$ [28]. On the contrary winter $\mathrm{PM}_{10}$ was a more potent inducer of DNA damage and reactive oxygen species (ROS) formation [29]. These differences were related to the chemical composition of the particles, with summer PM enriched in crustal elements and pro-inflammatory biogenic compounds [14,25], and winter PM characterized by a higher content in organic compounds (such as polycyclic aromatic hydrocarbons, PAHs) [14]. These results are in agreement with the international literature [26,30-35]. Indeed, the toxicological characterization of $\mathrm{PM}_{10}$ and coarse PM has received significant interest during the last decade of $20^{\text {th }}$ century and the beginning of $21^{\text {st }}$ century. The capability of $\mathrm{PM}_{10}$ to induce inflammation has been identified by several authors [36-39] and related to different PM components, such as endotoxins [30-32], metals and crustal elements [26,30,34], and possibly PAHs [33,35]. This evidence comprises the first lesson learned: an often neglected component of airborne PM i.e. biogenic-derived debris, which is seldom characterized, and natural occurring species (crustal elements) may trigger significant lung inflammation. This may also support the epidemiological evidence reporting increased mortality and hospitalization during summer peaks of air pollution for cardiopulmonary diseases [40-42]. However, the toxicological difference in PM samples from different seasons is not supported by all authors. For example, Dumax-Vortex et al. [43] showed similar elemental composition and biological effects for particles sampled in Manchester (UK) during summer and winter season, indicating that the seasonality might not be a relevant parameter in every region.

The capability of $\mathrm{PM}_{10}$ to induce damages to the DNA, oxidative species, and activation of the xenobiotic responsive element (XRE) is also a well-learned lesson (already reviewed in [44] and related to the content of organic compounds, such as PAHs and dioxins). An interesting study [45] reported the capability of $\mathrm{PM}_{10}$ to impair the antioxidant defense system in lung cells, therefore increasing the possibility of oxidative damages and eventually cell death. The relevance of $\mathrm{PM}_{10}$ to induce reactive species (both oxygen and nitrogen ones) is reviewed in detail by Donaldson and colleagues [24]. Other papers [46-48] reported clear association between $\mathrm{PM}_{10}$ oxidative properties and DNA damage. More recently a study by Morales-Bárcenas and co-workers [49] reported an alteration induced by $\mathrm{PM}_{10}$ on protease activity and cell invasion. The authors also concluded that this alteration, combined with inflammatory insults also promoted by airborne PM, is likely to increase the possibility of chronic lung diseases, including cancer. Accordingly, Quezada-Maldonado and colleagues reported [50] a $\mathrm{PM}_{10}$-associated deregulation of micro-RNAs (miRNAs) relevant for cellular pathways usually modified in cancer cells. In this context, future research should focus on the consequence of long-term exposure to PM from different seasons and with clearly different toxicological potency, for example, summer (inflammogenic) and winter $\mathrm{PM}_{10}$ (genotoxic) (Figure 1). 


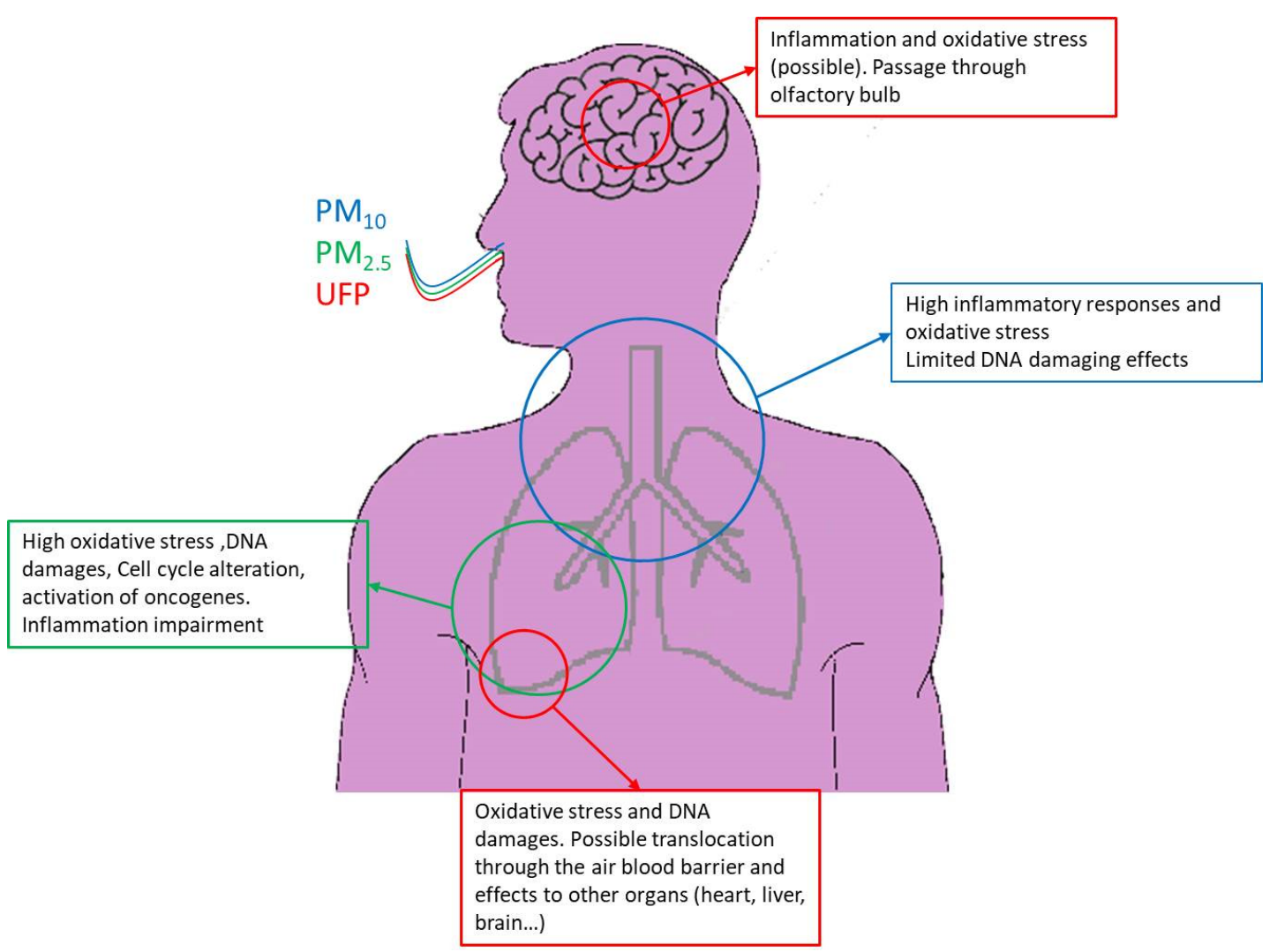

Figure 1. Summary of adverse effects determined in in vitro systems exposed to particulate matter with mean aerodynamic diameter lower than $10 \mu \mathrm{m}\left(\mathrm{PM}_{10}\right)$, fine particulate matter, lower than $2.5 \mu \mathrm{m}$ $\left(\mathrm{PM}_{2.5}\right)$, and ultrafine particle matter (UFP). $\mathrm{PM}_{10}$ coarse particulates deposit in the upper respiratory tract eliciting mainly inflammatory responses and formation of oxidative species. Particles rich in organic components may also trigger DNA damage and related responses. Fine PM deposits deeper in the respiratory tract and induces an increase in intracellular oxidative species. Consequent oxidative DNA damage and DNA damage adducts are related to xenobiotic responsive element (XRE) and antioxidant responsive element (ARE) genes expression. UFP deposit in the nose from where they may translocate to the brain through the olfactory bulb, inducing oxidative stress and inflammation in neural and glial cells. UFP may reach the alveoli from where they may translocate into the blood and target secondary organs such as the heart, brain, liver, etc.

\section{Fine $\mathbf{P M}\left(\mathrm{PM}_{2.5}\right)$}

Although an EU daily limit for $\mathrm{PM}_{2.5}$ exposure is not in operation (the EU directive 2008/50/EC refers to an annual mean of $20 \mu \mathrm{g} / \mathrm{m}^{3}$ in force from 1 January 2020), the World Health Organization (WHO) recommends a $24 \mathrm{~h}$ threshold of $25 \mu \mathrm{g} / \mathrm{m}^{3}$ (with an annual average of $10 \mu \mathrm{g} / \mathrm{m}^{3}$ ) for protection of human health. Despite this lack of a daily exposure limit, the EEA (https://www.eea.europa.eu/ data-and-maps/indicators/exceedance-of-air-quality-limit-3/assessment-5) also reports that $6 \%-8 \%$ of the urban population are exposed to concentrations in excess of the EU target value of $25 \mu \mathrm{g} / \mathrm{m}^{3}$, while $74 \%-81 \%$ are exposed to concentrations above the WHO recommended annual concentration. The significance of these exceedances is related to the latest epidemiological reports that identify fine PM as the fifth leading risk factor for death in the world, accounting for 4.2 million deaths and more than 103 million disability-adjusted life years lost [51,52].

It is therefore straightforward to understand the strong effort that has been devoted by many research groups in Europe and all over the world in identifying the key biological processes activated by $\mathrm{PM}_{2.5}$. The research conducted on Milan fine PM unraveled significant biological outcomes, which were only in part previously reported. Significantly, we show the capability of airborne fine PM to interact and impair one of the key cell processes that is cell division $[53,54]$, by altering the 
spindle assembly during prophase and metaphase. Although working on $\mathrm{PM}_{10}$, a recent study by Santibáñez-Andrade and co-workers [55] demonstrated that PM-induced cell division impairment is related to the disruption of the spindle assembly checkpoint. A correct cell division is essential to ensure that the replicated chromosomes are evenly separated in the daughter cells. In accordance, we reported that fine PM exposure increased the number of cells with micronuclei [53], providing additional evidence that relates PM exposure, genomic instability and, possibly, lung cancer onset (as reviewed in [56]). A typical feature of lung tumor cells is their ability to invade surrounding tissues and produce metastasis. Invasion potency has been related to cytoskeleton remodeling [57]. We extensively report that $\mathrm{PM}_{2.5}$ is able to determine significant modifications in the cell cytoskeleton, such as loss of stress fibers, modified actin structure, and increased membrane ruffling [54,58]. These data are supported by a recent publication by Chirino and colleagues [59]. These alterations were related to a significant relocation of cadherin- 1 and increased serpin-2 expression and heat shock protein 27 (HSP27) phosphorylation $[58,60]$. Furthermore, we and others showed that cytoskeleton alteration is also associated to pro-inflammatory signaling impairment in exposed lung cells [61,62], which may increase the susceptibility of lung tissue to infection and other diseases. Taken together, these results evidence how exposure to fine PM potentially contributes to all phases of the carcinogenic process. In addition, fine winter PM is able to activate a series of different pathways related to aryl hydrocarbon receptor (AhR) activation, nucleotide-binding oligomerization domain (NOD)-like receptor activation, and reactive oxygen species formation leading, among others, to XRE genes (Cyp1A1, Cyp1B1, AhRR) and antioxidant responsive element (ARE) genes (NQO1, HMOX-1, SOD, GCL, ALDH3A1) transcription, which eventually determines the increase of related protein levels $[58,63]$. The effects, reported by our studies, are associated also with increased DNA damage, mainly oxidative, as a result of the increased formation of ROS. Indeed, the increase in measured ROS after PM exposure correlated with $\gamma \mathrm{H} 2 \mathrm{AX}$ and 8-oxodG levels [53]. Increments of RNA levels of genes related to XRE and ARE are not new, and other authors reported this association with fine PM. The differential modulation of genes in cells exposed to $\mathrm{PM}_{2.5}$ samples, collected during different months and at different locations, is reported by Lauer and colleagues [64] and shows an increased expression of genes related to AhR activation (Cyp1A1) and oxidative stress (HMOX-1, NQO-1, ALDH3A1, AKR1C1). Similarly, another study by Zhou and collaborators [62] shows increased expression of ARE related genes. The increased expression of Cyp1A1, Cyp1B1, and AhRR genes after exposure to fine PM, also in relation to increased $\gamma \mathrm{H} 2 \mathrm{AX}$ levels, is reported by Borgie and co-workers [65] and a recent study by Mehta and colleagues [66] shows that PM is also able to impair the DNA repair mechanisms, therefore increasing PM mutagenic effects [67,68]. PM-derived activation of AhR was also shown to activate dendritic cells [69], which are essential in priming naïve T cells, therefore providing additional evidence relating airborne PM and immune responses. In this respect, it is pivotal to remember the interplay among the different response pathways within cells, as demonstrated by authors working on specific fine PM compounds, such as PAHs [33,70] (Figure 1).

The importance of epigenetics on the onset of several human diseases is largely documented [71-74] and, in this context, fine PM shows to significantly modulate micro RNAs (miRNAs). We reported the modulation of several miRNAs, among which miR-1246 and miR-146a were shown to be upregulated [58]. miR-146a is reported to be relevant for several non-transmissible and autoimmune human diseases [75,76]. Recently, the importance of long non-coding RNAs (lncRNAs) has been reported to explain the effects of $\mathrm{PM}_{2.5}$, thus demonstrating the complexity of interactions among cellular pathways activated by particles. A recent study by Li et al. [77] related IncRNAuc001.dgp.1, targeting miR-3607-5p, to the inflammatory properties of fine PM. Another study published in 2017 by Deng et al. [78] correlated the ability of $\mathrm{PM}_{2.5}$ to induce autophagy and cancer cell migration and invasion with increased expression of lncRNA loc146880. In $2017 \mathrm{Xu}$ et al. [79] showed that lncRNA LINC00341 is involved in PM-induced cell cycle arrest in G2/M phase. Interestingly, a more recent study by $\mathrm{Xu}$ et al. [80] reported the modulation of several exosome-related miRNAs, after exposure of bronchial cells to fine PM. In this respect, a few authors have already pointed out the importance of PM 
in modulating the release of exosomes/macrovesicles in exposed in vitro models [81,82], also in view of the potential role of these extracellular structures in mediating human diseases [83-85] (Figure 1).

Finally, in addition to the direct effects of fine PM on lung epithelial cells, authors are reporting interesting findings on the interaction of particulates with lung fluids. A study published in 2016 by Zhou et al. [86] reported the interaction of fine PM with lung fluids and demonstrated significant adverse effects on a cell membrane model while a recent paper by Dean, Elom, and Entwistle [87] proposed that the interaction of particulate with lung fluid may increase the exposure to heavy metals in urban areas, suggesting another possible mechanism for PM-related health effects.

\section{Ultrafine PM}

Ultrafine PM particles have received significant interest from researchers in recent years. This is mainly due to the understanding that PM mass concentration and PM particle number concentration are driven by different PM fractions, with the coarse and fine fraction leading the first and ultrafine particles leading the latter. Furthermore, the discussion of the importance of UFP on the explanation of health outcomes related to air pollution is gaining importance among researchers [88].

Epidemiological analyses show a relationship between UFP number concentration and both myocardial infarction [89] and cardiopulmonary health [90], although other papers report no or limited associations of UFP number concentration with health diseases [91,92] or mortality [93]. These differences may be related to the time lag between exposure to UFP and health status assessment, or to differences in the chemical properties/sources of measured UFP [94,95]. It is therefore straightforward to understand the request made by several authors to implement real-world exposure protocols for toxicological models relevant to PM and UFP [96,97]. Real-world direct exposure and environmentally-relevant doses will allow understanding of the toxicological effects of, possibly, unbiased PM and UFP samples, although representative of a specific area. However, given the significant artefacts produced by the particulate sampling and the extraction procedures, normally used for toxicological tests, only the modification of the paradigm so far applied, that is, sampling-extraction-exposure, into a new one based on direct exposure, may help to understand in more detail why particulates from different places of the world are driving similar (or not) health responses in the exposed population. According to this new paradigm, we reported recently [98] the effects of fine PM and UFP on bronchial in vitro models exposed at the air-liquid interface (ALI) directly under environmental conditions. Our results showed, for the first time, the feasibility of using in vitro models for direct exposure to airborne aerosols, and the importance of UFP number and median diameter in triggering oxidative responses in exposed cells. Significant correlations were also found between black carbon and PAHs/organic matter fractional concentration and XRE related genes. These results agree with those reported in another study [99], which evaluated the capability of different $\mathrm{PM}_{10}$ size fractions to induce DNA damage in a cell-free system, showing that UFP was a potent inducer of damage. Moreover, the direct exposure allowed us to identify the relative importance of primary anthropogenic and secondary PM, and related sources of emissions, on the effects determined in exposed cells and to find interesting correlation with human biomarkers of exposure [98,100]. Significantly, our approach was performed without complex procedures aimed at replicating airborne PM [101,102]. Despite the intrinsic relevance of direct exposure approaches, the number of papers reporting them is still limited, particularly in relation to the significant number of online monitors required to characterize particles during exposure. Classical approaches, based on preliminary particles sampling, are therefore still largely applied, with subsequent ALI $[103,104]$ or submersed exposure $[60,105,106]$. Since primary UFP sources are mainly related to combustion processes, we extensively analyze the toxicological effects of two main sources of fine and ultrafine PM, that are diesel and biomass combustion processes. Of relevance, we show [107] that, after only one hour of exposure, UFP induces complex transcriptomic modification relatable to possible cancer onset, as also reported by Longhin and collaborators [60]. These results are not new since the carcinogenic potency of diesel UFP is largely documented [108-112] but shed new light on the possible mechanism(s) of 
effects. In particular, we evidence that the epithelial-mesenchymal transition (EMT) may be regulated by STAT3 and related genes (HES1, HMOX1, IL6, IL24 and VEGF); the oncogene KRAS may be a key node in determining UFP effects by upregulating the expression of $E R E G$; and finally, the hypoxia inducible-factor-1a (HIF1a) may play a central role in UFP-related endothelial dysfunction. Building up on these results, we also show the ability of UFP to induce endothelial modification after exposure of lung epithelial cells to UFP [113] suggesting the relevance of cell signaling on endothelium modification and the possible onset of relevant effects at the cardiovascular level. Again, the cardiovascular effects of combustion particles are well documented [114,115], but the importance of second messengers in determining the onset of these health issues is poorly understood.

\section{Future Perspectives}

Given the increasing epidemiological and toxicological reports relating exposure to fine and ultrafine pollution with impairment of cognitive function [116-119], one of the primary areas for future toxicological studies should be the understanding of if and how UFP, after interaction with nasal and alveolar epithelial cells, may determine the activation of adverse cellular pathways in neuronal and glial cells [120]. So far the hypotheses are mainly related to the oxidative stress/inflammation paradigm, that will then determine significant damages in cells leading to cell modification and/or to cell death [121,122]. However it is not at all understood which component(s) of PM leads this process, if the carbonaceous core carbon of ultrafine PM is essential, if a specific class of compounds may be more likely responsible for adverse effects, or which processes are activated after exposure and, last but not least, if particle translocation occurs from primary (respiratory tract) to secondary target organs, such as the central nervous system (CNS), and the relevance of this process in triggering adverse effects. Therefore, we suggest that:

- the association of ALI exposure of lung cells to fine and ultrafine PM with neural cells, possibly in co-culture systems, is a primary goal in future toxicological studies for understanding the mode of action relating particulates with neurological effects.

The importance of understanding the biological effects of air pollution under realistic exposure conditions, which represent the real particle concentration exposure experienced by a population, has been largely evoked in recent papers [96]. Nonetheless the number of papers published during the last years is still scanty [98]. The reasons for this may be related to the complexity in setting up all the systems required for direct exposure (PM cut-off, particle diameters number distribution, ALI module, etc.) and for relevant chemical analysis (on-line vs. off-line procedures in relation to the time of exposure). Nonetheless ALI environmental exposure of lung epithelial models, possibly also in co-culture with other cell types, may allow the evaluation of selected PM fraction effects during specific hours of the day (i.e., commuting vs. working hours) and in different microenvironments. This new approach may also be used for repeated exposure experiments, taking advantage of the stability of ALI in vitro models during consecutive days. In this respect, we hope for:

- a significant increase of studies that will assess, using environmental exposure conditions, the association between PM and toxicological outcomes at doses and under sources directly representative of human exposure.

One of the most discussed questions among toxicologists is the identification of relevant correlation between different PM components and reported adverse effects. The correlations reported are always rather general: organic compounds, mostly PAHs, are associated with AhR activation and consequent Cyp enzymes' expression with possible DNA damage [53,123]; PM dimension and surface properties, inorganic components (metals and ions), and PAHs are associated to ROS formation and consequent oxidative damage; elemental carbon/black carbon core is also associated with ROS formation. Nonetheless, PM is a highly complex matrix and different researchers already reported that compounds belonging to the same chemical class (i.e., PAHs also in their oxidized or nitric form) may 
counteract each other's biological activities [33,124-126] competing for the same cellular substrate (like AhR), but triggering different biological responses (such as, but not limited to, XRE vs. inflammation). We therefore determine the following as important:

- the promotion and funding of a research effort (at European level at least) voted at the understanding of the molecules and, consequently, the sources of PM that are responsible of the observed toxicological effects, by means of a common platform for toxicological and chemical analysis, with the intent to obtain a common database on which to run data analysis. This information could, in turn, be useful for future air quality plans aimed at reducing the source of emission which impacts the health of exposed population more.

In recent years significant emphasis has been devoted to the effects of ultrafine carbon particles from primary combustion emission, namely vehicular emissions and, in part, biomass burning. Urban areas close to highways generally suffer from worse air quality, compared to inner city areas or low traffic zones $[127,128]$. This may be associated with higher impairment of health. Nonetheless, epidemiological studies are not able to properly consider these hot spots of exposure, mainly due to limited availability of personal exposure data. In the future we consider that

- the evaluation of the toxicological effects of micro areas, which are mostly impacted by vehicular emission, should also be considered for a more rationale planning of urban spaces and transports and for providing, in the end, equal access to clean and safe air to all of the population residing in a city.

In this respect, the fast moving transition of private mobility from internal combustion engine vehicles to full electric or hybrid vehicles requires a specific focus on the increasing incidence of non-exhaust vehicle emissions (such as brake wear, tire and road wear, etc.) on airborne PM [129-131]. Therefore a more focused evaluation of the toxicological impacts of fine and ultrafine particles deriving from these mechanical wear processes is desirable.

Finally, new emerging pollutants/environments of exposure are calling for new toxicological data in order to provide evidence relevant for their correct risk assessment and management. In the future research specific effort should be devoted to defining the toxicological impact of particulates characteristic of indoor environments [132,133], new emission sources, such as e-cigarettes [134], and new emerging pollutants such as micro and nano-plastics [135-137].

Although the effects of indoor air pollution on health are of mounting interest, research should continue to investigate outdoor PM; especially considering that at regional and local levels, the rapid climate changes forecasted for the next decades are predicted to significantly affect air quality, including PM concentrations and chemistry, and the concentrations of other pollutants, like ozone and other gases, with expected strong impact on public health $[138,139]$. Again, this contributes to the importance of approaching the issue of air pollution-related health effects by newly designed toxicological studies. These studies should take into account the chemical transformation of fine and ultrafine PM under variable environmental parameters (i.e., temperature, UV light, humidity) and the association with other airborne pollutants, in order to investigate possible synergistic effects on respiratory and cardiovascular systems.

Author Contributions: M.G. led manuscript drafting. E.M.L., M.G., and P.M. contributed to the manuscript until its final form. All authors have read and agreed to the published version of the manuscript.

Acknowledgments: The authors want to dedicate the present manuscript to the memory of Marina Camatini. She was head of the laboratory of Applied Cell Biology at the Department of Environmental Sciences and ideated and instituted the Research Center POLARIS leading it as Director first and then as President. She inspired several young researchers and her legacy is still motivating the researchers associated to Research Center POLARIS. The authors want also to acknowledge Fondazione Cariplo for funding TOSCA and "Biological effects and human health impacts of ultrafine particles sources" (Grant no. 2013-1038) projects; the Italian Ministry of Foreign Affairs and International Cooperation (MAECI); the Egyptian Academy of Scientific Research and Technology, Science and Technology Development Fund (STDF) for granting the project "Managing air quality and health 
risk: from airborne fine particulate (PM2.5) characterization to the biological mechanism of action," (PGR00786 to PM and ID: 26001); the Italian Ministry of Instruction, University and Research funding in the framework of the PRIN08, the project "Ultrafine particles and their health effects."; the region of Lombardy for the research funding of the project VESPA; the community of Milan for its financial support of the Prolife project. The authors want finally to thank all the researchers that collaborated during these years to make it possible to start and continue the research activities of POLARIS. Special thanks to Rossella Bengalli and Laura Capasso who shared part of the burden of laboratory analyses with E.M.L. and M.G.; and thanks to the Laboratory of Air pollution and Noise of the Norwegian Institute of Public Health (Oslo, Norway) for welcoming E.M.L. and M.G., especially to Jørn Andreas Holme for the insightful discussions and to Per E. Schwarze. M.G. wants to thank the colleagues from ENEA-SSPT-MET-INAT and from ENEA-SSPT-TECS-SAM for the fundamental collaboration and help in performing the direct environmental exposure in the context of the CARE campaign held in Rome in February 2017.

Conflicts of Interest: The authors declare no conflicts of interest.

\section{References}

1. EEA. Air Quality in Europe-2018 Report; EEA Report No 12/2018; Publications Office of the European Union: Luxembourg, 2018. [CrossRef]

2. Carugno, M.; Consonni, D.; Randi, G.; Catelan, D.; Grisotto, L.; Bertazzi, P.A.; Biggeri, A.; Baccini, M. Air pollution exposure, cause-specific deaths and hospitalizations in a highly polluted italian region. Environ. Res. 2016, 147, 415-424. [CrossRef]

3. Bigi, A.; Ghermandi, G. Trends and variability of atmospheric $\mathrm{PM}_{2.5}$ and $\mathrm{PM}_{10-2.5}$ concentration in the Po Valley, Italy. Atmos. Chem. Phys. Discuss. 2016, 1-19. [CrossRef]

4. Bigi, A.; Ghermandi, G.; Harrison, R.M. Analysis of the air pollution climate at a background site in the Po valley. J. Environ. Monit. 2012, 14, 552-563. [CrossRef] [PubMed]

5. Innocente, E.; Squizzato, S.; Visin, F.; Facca, C.; Rampazzo, G.; Bertolini, V.; Gandolfi, I.; Franzetti, A.; Ambrosini, R.; Bestetti, G. Influence of seasonality, air mass origin and particulate matter chemical composition on airborne bacterial community structure in the Po Valley, Italy. Sci. Total Environ. 2017, 593, 677-687. [CrossRef] [PubMed]

6. Conti, S.; Lafranconi, A.; Zanobetti, A.; Fornari, C.; Madotto, F.; Schwartz, J.; Cesana, G. Cardiorespiratory treatments as modifiers of the relationship between particulate matter and health: A case-only analysis on hospitalized patients in Italy. Environ. Res. 2015, 136, 491-499. [CrossRef] [PubMed]

7. Farina, F.; Sancini, G.; Mantecca, P.; Gallinotti, D.; Camatini, M.; Palestini, P. The acute toxic effects of particulate matter in mouse lung are related to size and season of collection. Toxicol. Lett. 2011, 202, $209-217$. [CrossRef]

8. Perrone, M.G.; Gualtieri, M.; Ferrero, L.; Porto, C.L.; Udisti, R.; Bolzacchini, E.; Camatini, M. Seasonal variations in chemical composition and in vitro biological effects of fine PM from Milan. Chemosphere 2010, 78. [CrossRef]

9. Chen, G.; Feng, Q.; Wang, J. Mini-review of microplastics in the atmosphere and their risks to humans. Sci. Total Environ. 2020, 703, 135504. [CrossRef]

10. Jan Kole, P.; Löhr, A.J.; Van Belleghem, F.G.A.J.; Ragas, A.M.J. Wear and tear of tyres: A stealthy source of microplastics in the environment. Int. J. Environ. Res. Public Health 2017, 14, 1265. [CrossRef]

11. Milani, M.; Pucillo, F.P.; Ballerini, M.; Camatini, M.; Gualtieri, M.; Martino, S. First evidence of tyre debris characterization at the nanoscale by focused ion beam. Mater. Charact. 2004, 52, 283-288. [CrossRef]

12. Lipfert, F.W. A critical review of the ESCAPE project for estimating long-term health effects of air pollution. Environ. Int. 2017, 99, 87-96. [CrossRef]

13. Gharibvand, L.; Beeson, W.L.; Knutsen, R.; Knutsen, S.F.; Shavlik, D.; Ghamsary, M.; Soret, S. The Association between Ambient Fine Particulate Air Pollution and Lung Cancer Incidence: Results from the AHSMOG-2 Study. Environ. Health Perspect. 2017, 125, 378-384. [CrossRef]

14. Gualtieri, M.; Øvrevik, J.; Holme, J.A.; Perrone, M.G.; Bolzacchini, E.; Schwarze, P.E.; Camatini, M. Differences in cytotoxicity versus pro-inflammatory potency of different PM fractions in human epithelial lung cells. Toxicol. In Vitro 2010, 24, 29-39. [CrossRef] [PubMed]

15. Alfaro-Moreno, E.; Nawrot, T.S.; Vanaudenaerde, B.M.; Hoylaerts, M.F.; Vanoirbeek, J.A.; Nemery, B.; Hoet, P.H.M. Co-cultures of multiple cell types mimic pulmonary cell communication in response to urban PM10. Eur. Respir. J. 2008, 32, 1184-1194. [CrossRef] [PubMed] 
16. Bennett, W.D.; Herbst, M.; Alexis, N.E.; Zeman, K.L.; Wu, J.; Hernandez, M.L.; Peden, D.B. Effect of inhaled dust mite allergen on regional particle deposition and mucociliary clearance in allergic asthmatics. Clin. Exp. Allergy 2011, 41, 1719-1728. [CrossRef] [PubMed]

17. Asgharian, B.; Hofmann, W.; Miller, F.J. Mucociliary clearance of insoluble particles from the tracheobronchial airways of the human lung. J. Aerosol Sci. 2001, 32, 817-832. [CrossRef]

18. Lansley, A.B. Mucociliary clearance and drug delivery via the respiratory tract. Adv. Drug Deliv. Rev. 1993, 11, 299-327. [CrossRef]

19. Moreda-Piñeiro, J.; Dans-Sánchez, L.; Sánchez-Piñero, J.; Turnes-Carou, I.; Muniategui-Lorenzo, S.; López-Mahía, P. Oral bioavailability estimation of toxic and essential trace elements in PM10. Atmos. Environ. 2019, 213, 104-115. [CrossRef]

20. Kastury, F.; Smith, E.; Karna, R.R.; Scheckel, K.G.; Juhasz, A.L. An inhalation-ingestion bioaccessibility assay (IIBA) for the assessment of exposure to metal(loid)s in PM10. Sci. Total Environ. 2018, 631-632, 92-104. [CrossRef]

21. Gao, P.; Guo, H.; Zhang, Z.; Ou, C.; Hang, J.; Fan, Q.; He, C.; Wu, B.; Feng, Y.; Xing, B. Bioaccessibility and exposure assessment of trace metals from urban airborne particulate matter (PM10 and PM2.5) in simulated digestive fluid. Environ. Pollut. 2018, 242, 1669-1677. [CrossRef]

22. Pavia, D.; Bateman, J.R.M.; Clarke, S.W. Deposition and clearance of inhaled particles. Clin. Respir. Physiol. 1980, 16, 335-366. [CrossRef]

23. Kuempel, E.D.; Sweeney, L.M.; Morris, J.B.; Jarabek, A.M. Advances in Inhalation Dosimetry Models and Methods for Occupational Risk Assessment and Exposure Limit Derivation. J. Occup. Environ. Hyg. 2015, 12, S18-S40. [CrossRef] [PubMed]

24. Donaldson, K.; Stone, V.; Borm, P.J.; Jimenez, L.A.; Gilmour, P.S.; Schins, R.P.; Knaapen, A.M.; Rahman, I.; Faux, S.P.; Brown, D.M.; et al. Oxidative stress and calcium signaling in the adverse effects of environmental particles (PM10). Free Radic. Biol. Med. 2003, 34, 1369-1382. [CrossRef]

25. Camatini, M.; Corvaja, V.; Pezzolato, E.; Mantecca, P.; Gualtieri, M. PM10-biogenic fraction drives the seasonal variation of proinflammatory response in A549 cells. Environ. Toxicol. 2012, 27. [CrossRef]

26. Michael, S.; Montag, M.; Dott, W. Pro-inflammatory effects and oxidative stress in lung macrophages and epithelial cells induced by ambient particulate matter. Environ. Pollut. 2013, 183, 19-29. [CrossRef]

27. Perrone, M.G.; Gualtieri, M.; Consonni, V.; Ferrero, L.; Sangiorgi, G.; Longhin, E.; Ballabio, D.; Bolzacchini, E.; Camatini, M. Particle size, chemical composition, seasons of the year and urban, rural or remote site origins as determinants of biological effects of particulate matter on pulmonary cells. Environ. Pollut. 2013, 176, 215-227. [CrossRef]

28. Bengalli, R.; Molteni, E.; Longhin, E.; Refsnes, M.; Camatini, M.; Gualtieri, M. Release of IL-1 $\beta$ triggered by milan Summer PM10: Molecular pathways involved in the cytokine release. BioMed Res. Int. 2013, 2013, 158093. [CrossRef]

29. Longhin, E.; Pezzolato, E.; Mantecca, P.; Holme, J.A.; Franzetti, A.; Camatini, M.; Gualtieri, M. Season linked responses to fine and quasi-ultrafine Milan PM in cultured cells. Toxicol. In Vitro 2013, 27, 551-559. [CrossRef]

30. Lyu, Y.; Su, S.; Wang, B.; Zhu, X.; Wang, X.; Zeng, E.Y.; Xing, B.; Tao, S. Seasonal and spatial variations in the chemical components and the cellular effects of particulate matter collected in Northern China. Sci. Total Environ. 2018, 627, 1627-1637. [CrossRef]

31. Jalava, P.I.; Happo, M.S.; Huttunen, K.; Sillanpää, M.; Hillamo, R.; Salonen, R.O.; Hirvonen, M.R. Chemical and microbial components of urban air PM cause seasonal variation of toxicological activity. Environ. Toxicol. Pharmacol. 2016, 40, 375-387. [CrossRef]

32. Hetland, R.B.; Cassee, F.R.; Låg, M.; Refsnes, M.; Dybing, E.; Schwarze, P.E. Cytokine release from alveolar macrophages exposed to ambient particulate matter: Heterogeneity in relation to size, city an season. Part. Fibre Toxicol. 2005, 2. [CrossRef] [PubMed]

33. Øvrevik, J.; Arlt, V.M.; Øya, E.; Nagy, E.; Mollerup, S.; Phillips, D.H.; Låg, M.; Holme, J.A. Differential effects of nitro-PAHs and amino-PAHs on cytokine and chemokine responses in human bronchial epithelial BEAS-2B cells. Toxicol. Appl. Pharmacol. 2010, 242, 270-280. [CrossRef] [PubMed]

34. Øvrevik, J.; Låg, M.; Holme, J.A.; Schwarze, P.E.; Refsnes, M. Cytokine and chemokine expression patterns in lung epithelial cells exposed to components characteristic of particulate air pollution. Toxicology 2009, 259, 46-53. [CrossRef] [PubMed] 
35. Manzano-León, N.; Serrano-Lomelin, J.; Sánchez, B.N.; Quintana-Belmares, R.; Vega, E.; Vázquez-López, I.; Rojas-Bracho, L.; López-Villegas, M.T.; Vadillo-Ortega, F.; De Vizcaya-Ruiz, A.; et al. TNF $\alpha$ and IL-6 responses to particulate matter in vitro: Variation according to PM size, season, and polycyclic aromatic hydrocarbon and soil content. Environ. Health Perspect. 2016, 124, 406-412. [CrossRef]

36. Schilirò, T.; Alessandria, L.; Bonetta, S.; Carraro, E.; Gilli, G. Inflammation response and cytotoxic effects in human THP-1 cells of size-fractionated PM10 extracts in a polluted urban site. Chemosphere 2016, 145, 89-97. [CrossRef]

37. Capasso, L.; Longhin, E.; Caloni, F.; Camatini, M.; Gualtieri, M. Synergistic inflammatory effect of PM10 with mycotoxin deoxynivalenol on human lung epithelial cells. Toxicon 2015, 104. [CrossRef]

38. Manzano-León, N.; Quintana, R.; Sánchez, B.; Serrano, J.; Vega, E.; Vázquez-López, I.; Rojas-Bracho, L.; López-Villegas, T.; O’Neill, M.S.; Vadillo-Ortega, F.; et al. Variation in the Composition and In Vitro Proinflammatory Effect of Urban Particulate Matter from Different Sites. J. Biochem. Mol. Toxicol. 2013, 27, 87-97. [CrossRef]

39. Pozzi, R.; De Berardis, B.; Paoletti, L.; Guastadisegni, C. Inflammatory mediators induced by coarse (PM2.5-10) and fine (PM2.5) urban air particles in RAW 264.7 cells. Toxicology 2003, 183, 243-254. [CrossRef]

40. Kim, S.E.; Honda, Y.; Hashizume, M.; Kan, H.; Lim, Y.H.; Lee, H.; Kim, C.T.; Yi, S.M.; Kim, H. Seasonal analysis of the short-term effects of air pollution on daily mortality in Northeast Asia. Sci. Total Environ. 2017, 576, 850-857. [CrossRef]

41. Goldberg, M.S.; Burnett, R.T.; Valois, M.F.; Flegel, K.; Bailar Iii, J.C.; Brook, J.; Vincent, R.; Radon, K. Associations between ambient air pollution and daily mortality among persons with congestive heart failure. Environ. Res. 2003, 91, 8-20. [CrossRef]

42. Stieb, D.M.; Judek, S.; Burnett, R.T. Meta-analysis of time-series studies of air pollution and mortality: Effects of gases and particles and the influence of cause of death, age, and season. J. Air Waste Manag. Assoc. 2002, 52, 470-484. [CrossRef] [PubMed]

43. Dumax-Vorzet, A.F.; Tate, M.; Walmsley, R.; Elder, R.H.; Povey, A.C. Cytotoxicity and genotoxicity of Urban particulate matter in mammalian cells. Mutagenesis 2015, 30, 621-633. [CrossRef] [PubMed]

44. Risom, L.; Møller, P.; Loft, S. Oxidative stress-induced DNA damage by particulate air pollution. Mutation Res. Fundam. Mol. Mech. Mutagen. 2005, 592, 119-137. [CrossRef] [PubMed]

45. Chirino, Y.I.; Sánchez-Pérez, Y.; Osornio-Vargas, Á.R.; Morales-Bárcenas, R.; Gutiérrez-Ruíz, M.C.; Segura-García, Y.; Rosas, I.; Pedraza-Chaverri, J.; García-Cuellar, C.M. PM10 impairs the antioxidant defense system and exacerbates oxidative stress driven cell death. Toxicol. Lett. 2010,193, 209-216. [CrossRef]

46. Yi, S.; Zhang, F.; Qu, F.; Ding, W. Water-Insoluble Fraction of Airborne Particulate Matter (PM10) Induces Oxidative Stress in Human Lung Epithelial A549 Cells. Environ. Toxicol. 2012, 29. [CrossRef]

47. Jung, M.H.; Kim, H.R.; Park, Y.J.; Park, D.S.; Chung, K.H.; Oh, S.M. Genotoxic effects and oxidative stress induced by organic extracts of particulate matter (PM10) collected from a subway tunnel in Seoul, Korea. Mutat. Res. Genet. Toxicol. Environ. Mutagen. 2012, 749, 39-47. [CrossRef]

48. Van Den Heuvel, R.; Den Hond, E.; Govarts, E.; Colles, A.; Koppen, G.; Staelens, J.; Mampaey, M.; Janssen, N.; Schoeters, G. Identification of PM10 characteristics involved in cellular responses in human bronchial epithelial cells (Beas-2B). Environ. Res. 2016, 149, 48-56. [CrossRef]

49. Morales-Bárcenas, R.; Chirino, Y.I.; Sánchez-Pérez, Y.; Osornio-Vargas, Á.R.; Melendez-Zajgla, J.; Rosas, I.; García-Cuellar, C.M. Particulate matter (PM10) induces metalloprotease activity and invasion in airway epithelial cells. Toxicol. Lett. 2015, 237, 167-173. [CrossRef]

50. Quezada-Maldonado, E.M.; Sánchez-Pérez, Y.; Chirino, Y.I.; Vaca-Paniagua, F.; García-Cuellar, C.M. miRNAs deregulation in lung cells exposed to airborne particulate matter (PM10) is associated with pathways deregulated in lung tumors. Environ. Pollut. 2018, 241, 351-358. [CrossRef]

51. Cohen, A.J.; Brauer, M.; Burnett, R.; Anderson, H.R.; Frostad, J.; Estep, K.; Balakrishnan, K.; Brunekreef, B.; Dandona, L.; Dandona, R.; et al. Estimates and 25-year trends of the global burden of disease attributable to ambient air pollution: An analysis of data from the Global Burden of Diseases Study 2015. Lancet 2017, 389, 1907-1918. [CrossRef]

52. Lelieveld, J.; Evans, J.S.; Fnais, M.; Giannadaki, D.; Pozzer, A. The contribution of outdoor air pollution sources to premature mortality on a global scale. Nature 2015, 525, 367-371. [CrossRef] [PubMed] 
53. Longhin, E.; Holme, J.A.; Gutzkow, K.B.; Arlt, V.M.; Kucab, J.E.; Camatini, M.; Gualtieri, M. Cell cycle alterations induced by urban PM2.5 in bronchial epithelial cells: Characterization of the process and possible mechanisms involved. Part. Fibre Toxicol. 2013, 10. [CrossRef] [PubMed]

54. Gualtieri, M.; Øvrevik, J.; Mollerup, S.; Asare, N.; Longhin, E.; Dahlman, H.J.; Camatini, M.; Holme, J.A. Airborne urban particles (Milan winter-PM2.5) cause mitotic arrest and cell death: Effects on DNA, mitochondria, AhR binding and spindle organization. Mutat. Res. Fundam. Mol. Mech. Mutagen. 2011, 713. [CrossRef] [PubMed]

55. Santibáñez-Andrade, M.; Sánchez-Pérez, Y.; Chirino, Y.I.; Morales-Bárcenas, R.; Herrera, L.A.; García-Cuellar, C.M. Airborne particulate matter induces mitotic slippage and chromosomal missegregation through disruption of the spindle assembly checkpoint (SAC). Chemosphere 2019, 235, 794-804. [CrossRef] [PubMed]

56. Santibáñez-Andrade, M.; Quezada-Maldonado, E.M.; Osornio-Vargas, Á.; Sánchez-Pérez, Y.; García-Cuellar, C.M. Air pollution and genomic instability: The role of particulate matter in lung carcinogenesis. Environ. Pollut. 2017, 229, 412-422. [CrossRef]

57. Niu, J.; Mo, Q.; Wang, H.; Li, M.; Cui, J.; Li, Z.; Li, Z. Invasion inhibition by a MEK inhibitor correlates with the actin-based cytoskeleton in lung cancer A549 cells. Biochem. Biophys. Res. Commun. 2012, 422, 80-84. [CrossRef]

58. Longhin, E.; Capasso, L.; Battaglia, C.; Proverbio, M.C.; Cosentino, C.; Cifola, I.; Mangano, E.; Camatini, M.; Gualtieri, M. Integrative transcriptomic and protein analysis of human bronchial BEAS-2B exposed to seasonal urban particulate matter. Environ. Pollut. 2016, 209. [CrossRef]

59. Chirino, Y.I.; García-Cuellar, C.M.; García-García, C.; Soto-Reyes, E.; Osornio-Vargas, Á.R.; Herrera, L.A.; López-Saavedra, A.; Miranda, J.; Quintana-Belmares, R.; Pérez, I.R.; et al. Airborne particulate matter in vitro exposure induces cytoskeleton remodeling through activation of the ROCK-MYPT1-MLC pathway in A549 epithelial lung cells. Toxicol. Lett. 2017, 272, 29-37. [CrossRef]

60. Longhin, E.; Camatini, M.; Bersaas, A.; Mantecca, P.; Mollerup, S. The role of SerpinB2 in human bronchial epithelial cells responses to particulate matter exposure. Arch. Toxicol. 2018, 92, 2923-2933. [CrossRef]

61. Longhin, E.; Holme, J.A.; Gualtieri, M.; Camatini, M.; Øvrevik, J. Milan winter fine particulate matter (wPM2.5) induces IL-6 and IL-8 synthesis in human bronchial BEAS-2B cells, but specifically impairs IL-8 release. Toxicol. In Vitro 2018, 52, 365-373. [CrossRef]

62. Zhou, Z.; Liu, Y.; Duan, F.; Qin, M.; Wu, F.; Sheng, W.; Yang, L.; Liu, J.; He, K. Transcriptomic analyses of the biological effects of airborne PM2.5 exposure on human bronchial epithelial cells. PLoS ONE 2015, 10, e0138267. [CrossRef] [PubMed]

63. Gualtieri, M.; Skuland, T.; Iversen, T.G.; Låg, M.; Schwarze, P.; Bilaničová, D.; Pojana, G.; Refsnes, M. Importance of agglomeration state and exposure conditions for uptake and pro-inflammatory responses to amorphous silica nanoparticles in bronchial epithelial cells. Nanotoxicology 2012, 6. [CrossRef] [PubMed]

64. Lauer, F.T.; Mitchell, L.A.; Bedrick, E.; McDonald, J.D.; Lee, W.Y.; Li, W.W.; Olvera, H.; Amaya, M.A.; Berwick, M.; Gonzales, M.; et al. Temporal-spatial analysis of U.S.-Mexico border environmental fine and coarse PM air sample extract activity in human bronchial epithelial cells. Toxicol. Appl. Pharmacol. 2009, 238, 1-10. [CrossRef] [PubMed]

65. Borgie, M.; Ledoux, F.; Verdin, A.; Cazier, F.; Greige, H.; Shirali, P.; Courcot, D.; Dagher, Z. Genotoxic and epigenotoxic effects of fine particulate matter from rural and urban sites in Lebanon on human bronchial epithelial cells. Environ. Res. 2015, 136, 352-362. [CrossRef] [PubMed]

66. Mehta, M.; Chen, L.C.; Gordon, T.; Rom, W.; Tang, M. shong. Particulate matter inhibits DNA repair and enhances mutagenesis. Mutat. Res. Genet. Toxicol. Environ. Mutagen. 2008, 657, 116-121. [CrossRef]

67. Bonetta, S.; Bonetta, S.; Schilirò, T.; Ceretti, E.; Feretti, D.; Covolo, L.; Vannini, S.; Villarini, M.; Moretti, M.; Verani, M.; et al. Mutagenic and genotoxic effects induced by PM0.5 of different Italian towns in human cells and bacteria: The MAPEC_LIFE study. Environ. Pollut. 2019, 245, 1124-1135. [CrossRef]

68. Landkocz, Y.; Ledoux, F.; André, V.; Cazier, F.; Genevray, P.; Dewaele, D.; Martin, P.J.; Lepers, C.; Verdin, A.; Courcot, L.; et al. Fine and ultrafine atmospheric particulate matter at a multi-influenced urban site: Physicochemical characterization, mutagenicity and cytotoxicity. Environ. Pollut. 2017, 221. [CrossRef]

69. Castañeda, A.R.; Pinkerton, K.E.; Bein, K.J.; Magaña-Méndez, A.; Yang, H.T.; Ashwood, P.; Vogel, C.F.A. Ambient particulate matter activates the aryl hydrocarbon receptor in dendritic cells and enhances Th17 polarization. Toxicol. Lett. 2018, 292, 85-96. [CrossRef] 
70. Bach, N.; Bølling, A.K.; Brinchmann, B.C.; Totlandsdal, A.I.; Skuland, T.; Holme, J.A.; Låg, M.; Schwarze, P.E.; Øvrevik, J. Cytokine responses induced by diesel exhaust particles are suppressed by PAR-2 silencing and antioxidant treatment, and driven by polar and non-polar soluble constituents. Toxicol. Lett. 2015, 238, 72-82. [CrossRef]

71. Schraufnagel, D.E.; Balmes, J.R.; Cowl, C.T.; De Matteis, S.; Jung, S.H.; Mortimer, K.; Perez-Padilla, R.; Rice, M.B.; Riojas-Rodriguez, H.; Sood, A.; et al. Air Pollution and Noncommunicable Diseases: A Review by the Forum of International Respiratory Societies' Environmental Committee, Part 1: The Damaging Effects of Air Pollution. Chest 2019, 155, 409-416. [CrossRef]

72. Kawasaki, H.; Abe, H. Epigenetics in cancer and inflammation. Pers. Med. Univ. 2012, 1, 7-12. [CrossRef]

73. Traboulsi, H.; Guerrina, N.; Iu, M.; Maysinger, D.; Ariya, P.; Baglole, C.J. Inhaled pollutants: The molecular scene behind respiratory and systemic diseases associated with ultrafine particulate matter. Int. J. Mol. Sci. 2017, 18, 243. [CrossRef] [PubMed]

74. $\mathrm{Hu}, \mathrm{J} . ; \mathrm{Yu}, \mathrm{Y}$. Epigenetic response profiles into environmental epigenotoxicant screening and health risk assessment: A critical review. Chemosphere 2019, 226, 259-272. [CrossRef] [PubMed]

75. Li, Y.; Qiu, C.; Tu, J.; Geng, B.; Yang, J.; Jiang, T.; Cui, Q. HMDD v2.0: A database for experimentally supported human microRNA and disease associations. Nucleic Acids Res. 2014, 42, 1070-1074. [CrossRef]

76. Saba, R.; Sorensen, D.L.; Booth, S.A. MicroRNA-146a: A dominant, negative regulator of the innate immune response. Front. Immunol. 2014, 5, 578. [CrossRef]

77. Li, X.; Jia, Y.; Nan, A.; Zhang, N.; Zhou, H.; Chen, L.; Pan, X.; Qiu, M.; Zhu, J.; Zhang, H.; et al. CircRNA104250 and lncRNAuc001.dgp.1 promote the PM2.5-induced inflammatory response by co-targeting miR-3607-5p in BEAS-2B cells. Environ. Pollut. 2020, 258, 113749. [CrossRef]

78. Deng, X.; Feng, N.; Zheng, M.; Ye, X.; Lin, H.; Yu, X.; Gan, Z.; Fang, Z.; Zhang, H.; Gao, M.; et al. PM2.5 exposure-induced autophagy is mediated by lncRNA loc146880 which also promotes the migration and invasion of lung cancer cells. Biochim. Biophys. Acta General Subj. 2017, 1861, 112-125. [CrossRef]

79. Xu, Y.; Wu, J.; Peng, X.; Yang, T.; Liu, M.; Chen, L.; Dai, X.; Wang, Z.; Yang, C.; Yan, B.; et al. LncRNA LINC00341 mediates PM 2.5-induced cell cycle arrest in human bronchial epithelial cells. Toxicol. Lett. 2017, 276, 1-10. [CrossRef]

80. Xu, Z.; Wang, N.; Xu, Y.; Hua, L.; Zhou, D.; Zheng, M.; Deng, X. Effects of chronic PM2.5 exposure on pulmonary epithelia: Transcriptome analysis of mRNA-exosomal miRNA interactions. Toxicol. Lett. 2019, 316, 49-59. [CrossRef]

81. Neri, T.; Longhin, E.M.; Petrini, S.; Gualtieri, M.; Lombardi, S.; Carmazzi, Y. Balia, C.; Scalise, V.; Camatini, M.; Pedrinelli, R.; Paggiaro, P.; Celi, A. European Respiratory Society Annual Congress 2010. Eur. Respir. J. 2013, 42, P3876.

82. Martin, P.J.; Héliot, A.; Tremolet, G.; Landkocz, Y.; Dewaele, D.; Cazier, F.; Ledoux, F.; Courcot, D. Cellular response and extracellular vesicles characterization of human macrophages exposed to fine atmospheric particulate matter. Environ. Pollut. 2019, 254. [CrossRef]

83. Boda, E.; Rigamonti, A.E.; Bollati, V. Understanding the effects of air pollution on neurogenesis and gliogenesis in the growing and adult brain. Curr. Opin. Pharmacol. 2020, 50, 61-66. [CrossRef] [PubMed]

84. Levänen, B.; Bhakta, N.R.; Paredes, P.T.; Barbeau, R.; Hiltbrunner, S.; Pollack, J.L.; Sköld, C.M.; Svartengren, M.; Grunewald, J.; Gabrielsson, S.; et al. Altered microRNA profiles in bronchoalveolar lavage fluid exosomes in asthmatic patients. J. Allergy Clin. Immunol. 2013, 131, 18-23. [CrossRef] [PubMed]

85. Fujita, Y.; Kosaka, N.; Araya, J.; Kuwano, K.; Ochiya, T. Extracellular vesicles in lung microenvironment and pathogenesis. Trends Mol. Med. 2015, 21, 533-542. [CrossRef] [PubMed]

86. Zhou, Q.; Wang, L.; Cao, Z.; Zhou, X.; Yang, F.; Fu, P.; Wang, Z.; Hu, J.; Ding, L.; Jiang, W. Dispersion of atmospheric fine particulate matters in simulated lung fluid and their effects on model cell membranes. Sci. Total Environ. 2016, 542, 36-43. [CrossRef] [PubMed]

87. Dean, J.R.; Elom, N.I.; Entwistle, J.A. Use of simulated epithelial lung fluid in assessing the human health risk of $\mathrm{Pb}$ in urban street dust. Sci. Total Environ. 2017, 579, 387-395. [CrossRef]

88. Chen, R.; Hu, B.; Liu, Y.; Xu, J.; Yang, G.; Xu, D.; Chen, C. Beyond PM2.5: The role of ultrafine particles on adverse health effects of air pollution. Biochim. Biophys. Acta General Subj. 2016, 1860, 2844-2855. [CrossRef]

89. Wolf, K.; Schneider, A.; Breitner, S.; Meisinger, C.; Heier, M.; Cyrys, J.; Kuch, B.; von Scheidt, W.; Peters, A.; KORA Study Group. Associations between short-term exposure to particulate matter and ultrafine particles and myocardial infarction in Augsburg, Germany. Int. J. Hyg. Environ. Health 2015, 218, 535-542. [CrossRef] 
90. Liu, J.Y.; Hsiao, T.C.; Lee, K.Y.; Chuang, H.C.; Cheng, T.J.; Chuang, K.J. Association of ultrafine particles with cardiopulmonary health among adult subjects in the urban areas of northern Taiwan. Sci. Total Environ. 2018, 627, 211-215. [CrossRef]

91. Møller, K.L.; Brauer, C.; Mikkelsen, S.; Bonde, J.P.; Loft, S.; Helweg-Larsen, K.; Thygesen, L.C. Cardiovascular disease and long-term occupational exposure to ultrafine particles: A cohort study of airport workers. Int. J. Hyg. Environ. Health 2020, 223, 214-219. [CrossRef]

92. Fuller, C.H.; Williams, P.L.; Mittleman, M.A.; Patton, A.P.; Spengler, J.D.; Brugge, D. Response of biomarkers of inflammation and coagulation to short-term changes in central site, local, and predicted particle number concentrations. Ann. Epidemiol. 2015, 25, 505-511. [CrossRef] [PubMed]

93. Lanzinger, S.; Schneider, A.; Breitner, S.; Stafoggia, M.; Erzen, I.; Dostal, M.; Pastorkova, A.; Bastian, S.; Cyrys, J.; Zscheppang, A.; et al. Associations between ultrafine and fine particles and mortality in five central European cities-Results from the UFIREG study. Environ. Int. 2016, 88, 44-52. [CrossRef] [PubMed]

94. de Jesus, A.L.; Rahman, M.M.; Mazaheri, M.; Thompson, H.; Knibbs, L.D.; Jeong, C.; Evans, G.; Nei, W.; Ding, A.; Qiao, L.; et al. Ultrafine particles and PM2.5 in the air of cities around the world: Are they representative of each other? Environ. Int. 2019, 129, 118-135. [CrossRef]

95. Xue, W.; Xue, J.; Shirmohammadi, F.; Sioutas, C.; Lolinco, A.; Hasson, A.; Kleeman, M.J. Day-of-week patterns for ultrafine particulate matter components at four sites in California. Atmos. Environ. 2019, 222, 117088. [CrossRef]

96. Lelieveld, J.; Pöschl, U. Chemists can help to solve the air-pollution health crisis. Nature 2017, 551, $291-293$. [CrossRef] [PubMed]

97. Stone, V.; Miller, M.R.; Clift, M.J.; Elder, A.; Mills, N.L.; Møller, P.; Schins, R.P.; Vogel, U.; Kreyling, W.G.; Alstrup Jensen, K.; et al. Nanomaterials versus ambient ultrafine particles: An opportunity to exchange toxicology knowledge. Environ. Health Perspect. 2017, 125, 1-17. [CrossRef]

98. Gualtieri, M.; Grollino, M.G.; Consales, C.; Costabile, F.; Manigrasso, M.; Avino, P.; Aufderheide, M.; Cordelli, E.; Di Liberto, L.; Petralia, E.; et al. Is it the time to study air pollution effects under environmental conditions? A case study to support the shift of in vitro toxicology from the bench to the field. Chemosphere 2018, 207, 552-564. [CrossRef]

99. Price, H.D.; Jones, T.P.; BéruBé, K.A. Resolution of the mediators of in vitro oxidative reactivity in size-segregated fractions that may be masked in the urban PM10 cocktail. Sci. Total Environ. 2014, 485-486, 588-595. [CrossRef]

100. Costabile, F.; Gualtieri, M.; Canepari, S.; Tranfo, G.; Consales, C.; Grollino, M.G.; Paci, E.; Petralia, E.; Pigini, D.; Simonetti, G. Evidence of association between aerosol properties and in-vitro cellular oxidative response to PM1, oxidative potential of PM2.5, a biomarker of RNA oxidation, and its dependency on combustion sources. Atmos. Environ. 2019, 213, 444-455. [CrossRef]

101. Cacciottolo, M.; Morgan, T.E.; Saffari, A.A.; Shirmohammadi, F.; Forman, H.J.; Sioutas, C.; Finch, C.E. Traffic-related air pollutants (TRAP-PM) promote neuronal Amyloidogenesis through oxidative damage to lipid rafts. Free Radic. Biol. Med. 2020, 147, 242-251. [CrossRef]

102. Taghvaee, S.; Mousavi, A.; Sowlat, M.H.; Sioutas, C. Development of a novel aerosol generation system for conducting inhalation exposures to ambient particulate matter (PM). Sci. Total Environ. 2019, 665, 1035-1045. [CrossRef] [PubMed]

103. Leclercq, B.; Happillon, M.; Antherieu, S.; Hardy, E.M.; Alleman, L.Y.; Grova, N.; Perdrix, E.; Appenzeller, B.M.; Guidice, J.M.; Coddeville, P.; et al. Differential responses of healthy and chronic obstructive pulmonary diseased human bronchial epithelial cells repeatedly exposed to air pollution-derived PM 4. Environ. Pollut. 2016, 218, 1074-1088. [CrossRef] [PubMed]

104. Leclercq, B.; Kluza, J.; Antherieu, S.; Sotty, J.; Alleman, L.Y.; Perdrix, E.; Loyens, A.; Coddeville, P.; Guidice, J.M.; Marchetti, P.; et al. Air pollution-derived PM2.5 impairs mitochondrial function in healthy and chronic obstructive pulmonary diseased human bronchial epithelial cells. Environ. Pollut. 2018, 243, 1434-1449. [CrossRef] [PubMed]

105. Corsini, E.; Ozgen, S.; Papale, A.; Galbiati, V.; Lonati, G.; Fermo, P.; Corbella, L.; Valli, G.; Bernardoni, V.; Dell'Acqua, M.; et al. Insights on wood combustion generated proinflammatory ultrafine particles (UFP). Toxicol. Lett. 2017, 266, 74-84. [CrossRef] 
106. Borgie, M.; Dagher, Z.; Ledoux, F.; Verdin, A.; Cazier, F.; Martin, P.; Hachimi, A.; Shirali, P.; Greige-Gerges, H.; Courcot, D. Comparison between ultrafine and fine particulate matter collected in Lebanon: Chemical characterization, in vitro cytotoxic effects and metabolizing enzymes gene expression in human bronchial epithelial cells. Environ. Pollut. 2015, 205, 250-260. [CrossRef]

107. Grilli, A.; Bengalli, R.; Longhin, E.; Capasso, L.; Proverbio, M.C.; Forcato, M.; Bicciato, S.; Gualtieri, M.; Battaglia, C.; Camatini, M. Transcriptional profiling of human bronchial epithelial cell BEAS-2B exposed to diesel and biomass ultrafine particles. BMC Genomics 2018, 19, 302. [CrossRef]

108. Loomis, D.; Grosse, Y.; Lauby-Secretan, B.; El Ghissassi, F.; Bouvard, V.; Benbrahim-Tallaa, L.; Guha, N.; Baan, R.; Mattock, H.; Straif, K. The carcinogenicity of outdoor air pollution. Lancet Oncol. 2013, 14, 1262-1263. [CrossRef]

109. Villeneuve, P.J.; Parent, M.É.; Sahni, V.; Johnson, K.C. Occupational exposure to diesel and gasoline emissions and lung cancer in Canadian men. Environ. Res. 2011, 111, 727-735. [CrossRef]

110. Krauskopf, J.; Caiment, F.; van Veldhoven, K.; Chadeau-Hyam, M.; Sinharay, R.; Chung, K.F.; Cullinan, P.; Collins, P.; Barratt, B.; Kelly, F.J.; et al. The human circulating miRNome reflects multiple organ disease risks in association with short-term exposure to traffic-related air pollution. Environ. Int. 2018, 113, $26-34$. [CrossRef]

111. Lewtas, J. Air pollution combustion emissions: Characterization of causative agents and mechanisms associated with cancer, reproductive, and cardiovascular effects. Mutat. Res. Rev. Mutat. Res. 2007, 636, 95-133. [CrossRef]

112. Claxton, L.D. The history, genotoxicity, and carcinogenicity of carbon-based fuels and their emissions. Part 3: Diesel and gasoline. Mutat. Res. Rev. Mutat. Res. 2015, 763, 30-85. [CrossRef]

113. Bengalli, R.; Zerboni, A.; Marchetti, S.; Longhin, E.; Priola, M.; Camatini, M.; Mantecca, P. In vitro pulmonary and vascular effects induced by different diesel exhaust particles. Toxicol. Lett. 2019, 306, 13-24. [CrossRef] [PubMed]

114. Rider, C.F.; Carlsten, C. Air pollution and DNA methylation: Effects of exposure in humans. Clin. Epigenet. 2019, 11, 1-15. [CrossRef] [PubMed]

115. Robertson, S.; Miller, M.R. Ambient air pollution and thrombosis. Part. Fibre Toxicol. 2018, 15, 1-16. [CrossRef] [PubMed]

116. Solaimani, P.; Saffari, A.; Sioutas, C.; Bondy, S.C.; Campbell, A. Exposure to ambient ultrafine particulate matter alters the expression of genes in primary human neurons. NeuroToxicology 2017, 58, 50-57. [CrossRef] [PubMed]

117. Kim, S.Y.; Kim, J.K.; Park, S.H.; Kim, B.G.; Jang, A.S.; Oh, S.H.; Lee, J.H.; Suh, M.W.; Park, M.K. Effects of inhaled particulate matter on the central nervous system in mice. NeuroToxicology 2018, 67, 169-177. [CrossRef]

118. Costa, L.G.; Cole, T.B.; Dao, K.; Chang, Y.C.; Garrick, J.M. Developmental impact of air pollution on brain function. Neurochem. Int. 2019, 131, 104580. [CrossRef]

119. Lucchini, R.G.; Dorman, D.C.; Elder, A.; Veronesi, B. Neurological impacts from inhalation of pollutants and the nose-brain connection. NeuroToxicology 2012, 33, 838-841. [CrossRef]

120. Zhang, H.; Haghani, A.; Mousavi, A.H.; Cacciottolo, M.; D’Agostino, C.; Safi, N.; Sowlat, M.H.; Sioutas, C.; Morgan, T.E.; Finch, C.E.; et al. Cell-based assays that predict in vivo neurotoxicity of urban ambient nano-sized particulate matter. Free Radic. Biol. Med. 2019, 145, 33-41. [CrossRef]

121. Hajipour, S.; Farbood, Y.; Gharib-Naseri, M.K.; Goudarzi, G.; Rashno, M.; Maleki, H.; Bakhtiari, N.; Nesari, A.; Khoshnam, S.E.; Dianat, M.; et al. Exposure to ambient dusty particulate matter impairs spatial memory and hippocampal LTP by increasing brain inflammation and oxidative stress in rats. Life Sci. 2020, 242, 117210. [CrossRef]

122. Chew, S.; Kolosowska, N.; Saveleva, L.; Malm, T.; Kanninen, K.M. Neurochemistry International Impairment of mitochondrial function by particulate matter: Implications for the brain. Neurochem. Int. 2020, 135, 104694. [CrossRef] [PubMed]

123. Marchetti, S.; Hassan, S.K.; Shetaya, W.H.; El-Mekawy, A.; Mohamed, E.F.; Mohammed, A.M.; El-Abssawy, A.A.; Bengalli, R.; Colombo, A.; Gualtieri, M.; et al. Seasonal variation in the biological effects of PM2.5 from greater cairo. Int. J. Mol. Sci. 2019, 20, 4970. [CrossRef] [PubMed] 
124. Pěnčíková, K.; Ciganek, M.; Neča, J.; Illés, P.; Dvořák, Z.; Vondráček, J.; Machala, M. Modulation of endocrine nuclear receptor activities by polyaromatic compounds present in fractionated extracts of diesel exhaust particles. Sci. Total Environ. 2019, 677, 626-636. [CrossRef] [PubMed]

125. Vondráček, J.; Pěnčíková, K.; Neča, J.; Ciganek, M.; Grycová, A.; Dvořák, Z.; Machala, M. Assessment of the aryl hydrocarbon receptor-mediated activities of polycyclic aromatic hydrocarbons in a human cell-based reporter gene assay. Environ. Pollut. 2017, 220, 307-316. [CrossRef] [PubMed]

126. Procházková, J.; Strapáčová, S.; Svržková, L.; Andrysík, Z.; Hýžd’alová, M.; Hrubá, E.; Pěnčíková, K.; Líbalová, H.; Topinka, J.; Kléma, J.; et al. Adaptive changes in global gene expression profile of lung carcinoma A549 cells acutely exposed to distinct types of AhR ligands. Toxicol. Lett. 2018, 292, 162-174. [CrossRef] [PubMed]

127. Joerger, V.M.; Pryor, S.C. Ultrafine particle number concentrations and size distributions around an elevated highway viaduct. Atmos. Pollut. Res. 2018, 9, 714-722. [CrossRef]

128. Saha, P.K.; Zimmerman, N.; Malings, C.; Hauryliuk, A.; Li, Z.; Snell, L.; Subramanian, R.; Lipsky, E.; Apte, J.S.; Robinson, A.L.; et al. Quantifying high-resolution spatial variations and local source impacts of urban ultrafine particle concentrations. Sci. Total Environ. 2019, 655, 473-481. [CrossRef]

129. Timmers, V.R.J.H.; Achten, P.A.J. Non-exhaust PM emissions from electric vehicles. Atmos. Environ. 2016, 134, 10-17. [CrossRef]

130. Qian, Y.; Li, Z.; Yu, L.; Wang, X.; Lu, X. Review of the state-of-the-art of particulate matter emissions from modern gasoline fueled engines. Appl. Energy 2019, 238, 1269-1298. [CrossRef]

131. Singh, V.; Biswal, A.; Kesarkar, A.P.; Mor, S.; Ravindra, K. High resolution vehicular PM10 emissions over megacity Delhi: Relative contributions of exhaust and non-exhaust sources. Sci. Total Environ. 2020, 699, 134273. [CrossRef]

132. Slezakova, K.; de Oliveira Fernandes, E.; Pereira, M.C. Assessment of ultrafine particles in primary schools: Emphasis on different indoor microenvironments. Environ. Pollut. 2019, 246, 885-895. [CrossRef] [PubMed]

133. Manigrasso, M.; Vitali, M.; Protano, C.; Avino, P. Temporal evolution of ultrafine particles and of alveolar deposited surface area from main indoor combustion and non-combustion sources in a model room. Sci. Total Environ. 2017, 598, 1015-1026. [CrossRef] [PubMed]

134. Takahashi, Y.; Kanemaru, Y.; Fukushima, T.; Eguchi, K.; Yoshida, S.; Miller-Holt, J.; Jones, I. Chemical analysis and in vitro toxicological evaluation of aerosol from a novel tobacco vapor product: A comparison with cigarette smoke. Regul. Toxicol. Pharmacol. 2018, 92, 94-103. [CrossRef] [PubMed]

135. Xu, M.; Halimu, G.; Zhang, Q.; Song, Y.; Fu, X.; Li, Y.; Li, Y.; Zhang, H. Internalization and toxicity: A preliminary study of effects of nanoplastic particles on human lung epithelial cell. Sci. Total Environ. 2019, 694. [CrossRef] [PubMed]

136. Barbosa, F.; Adeyemi, J.A.; Bocato, M.Z.; Campiglia, A. A critical viewpoint on current issues, limitations, and future research needs on micro- and nanoplastic studies: From the detection to the toxicological assessment. Environ. Res. 2020, 109089. [CrossRef] [PubMed]

137. Prata, J.C. Airborne microplastics: Consequences to human health? Environ. Pollut. 2018, 234, 115-126. [CrossRef]

138. San José, R.; Pérez, J.L.; Pérez, L.; Gonzalez Barras, R.M. Effects of climate change on the health of citizens modelling urban weather and air pollution. Energy 2018, 165, 53-62. [CrossRef]

139. Sun, S.; Tian, L.; Cao, W.; Lai, P.C.; Wong, P.P.; Lee, R.S.; Mason, T.G.; Krämer, A.; Wong, C.M. Urban climate modified short-term association of air pollution with pneumonia mortality in Hong Kong. Sci. Total Environ. 2019, 646, 618-624. [CrossRef]

(C) 2020 by the authors. Licensee MDPI, Basel, Switzerland. This article is an open access article distributed under the terms and conditions of the Creative Commons Attribution (CC BY) license (http://creativecommons.org/licenses/by/4.0/). 